\title{
The Model of Buried Kimberlite Field \\ Based on Its Reflection in Postkimberlite Reservoir Rocks (by the Example of Yakutian Province)
}

Saltykov, O.G. ${ }^{1}$, Erinchek, Yu.M. ${ }^{1}$, and Milshtein, E.D. ${ }^{1}$

1. Geological Research Institute (VSEGEI), St. Petersburg 199106, Russia

\section{Introduction}

Evidence that the presence of kimberlite fields can be determined from peculiarities in the structure, lithology and composition of postkimberlite sediments is based on extensive date gathered during the study of Yakutian diamondiferous province in Siberia. The theoretical precondition to offered elaboration is the location of diamond-bearing kimberlites in the areas of archonic cratonisation. During platform stage these areas were stable and characterized by a conservative type of evolution. It results in specific features of volcanogenic-sedimentary cover, including its upper (postkimberlite) sedimentary horizons.

The epochs of kimberlite manifestation correspond to stratigraphical breaks and last weathering of the territories. (Brakhfogel, 1984). After that thin rhythmic sedimentation gradually covered all territory surround kimberlite field. Thin fine-rhythmic series with a lot of small-amplitude cyclothems formed in field vicinities. Coarse-clastic bed containing clay products of weathering zone which are normal for the low levels of these cyclothems show proximity of removal areas. The areas of thin continental sediments are the favourable for detection of buried kimberlites.

\section{Reflection of the field in postkimberlite sediments}

\subsection{Peculiarities of postkimberlite sediments}

Immediately adjacent to the kimberlite fields, there are normally several horizons showing elevated concentration of kimberlitic minerals in postkimberlite cyclothems. These can often cover an extensive rang of stratigraphic levels within a particular supergroup, a phenomenon that results from the long term erosion of kimberlite fields which generally tend to be associated with paleo-updoming. This would ensure a continuos supply of the products of kimberlite erosion over a prolonged period with input to the terrigeniuos reservoir rocks. Concentration of kimberlitic minerals tend to be localised within areas where their hosts overlie kimberlite country rock showing dissected paleo-relief.

Lithological heterogeneity and polyfaciesty of rocks containing kimberlitic minerals is the second significant reflection of kimberlite field in postkimberlit sediments. Elevated concentration of kimberlitic minerals are noted in fine-grained sediments as well as in coars clastics in the vicinity of there source. Indicator minerals can occur within proximal facies of there hosts both continental and coastal genesis. (Taranenko et.al., 1983; Saltykov et. al., 1991; Finshtein, 1981). The common distinctive feature of postkimberlite cyclothems adjacent to the field is the occurrence in them attributes of proximity with removal areas. Continental deposits (alluvials, shallow-water streams proluvial, etc.) are commonly noted for their poor sorting and poor rounding of their constituent particles, variation of granulometric composition. Basin (coastal) deposits (near-shore, beach, logoonal, shallaw-water, etc.) contain both well rounded and sub-angular particles. Occurrence of kimberlitic mineral aureoles in proximal continental deposits as well as there large size exceed that of host basin matrix are the most persuasive evidence of the presence of kimberlite field.

\subsection{Distribution of kimberlitic minerals in the postkimberlite reservoir rocks}

Heterogeneous distribution and the typomorhic diversity of kimberlitic minerals in the terrigeniuos reservoir rocks provide evidence of the proximity of the field. Kimberlitic mineral aureoles in postkimberlite reservoirs adjacent to kimberlite fields are, as a rule noted for the high concentrations of 
minerals, a polymineralic suite, poor sorting and the presence of slightly abraded kimberlitic minerals, especially those which cannot survive long tansport. Kimberlite mineral concentrations can range from tens to thousands of grains per 10 litre sample, with individual sizes of grains varying from decimals of a millimeter to $6 \mathrm{~mm}$. the proportion of grains exceeding $1 \mathrm{~mm}$ is generally 10 $20 \%$, with fine grains prevailing (Afanasiev and Zinchuk, 1987; Kharkiv, 1978). Proximal aureoles are characterized by a polymineralic range representing all (or at least the majority) of those present in the source. These are normally pyrope, picroilmenite, chrome spinel and chrome diopsid. Other minerals such as olivine and zircon are also recorded along with occasional fragments of kimberlite and mineral intergrowths and certain low density minerals. With increasing distance of transport, aureoles are transformed from polymineralic to monomineralic assemblages. The ratio of garnet to ilmenite is an important factor in this respect. The latter, being heavier, settle out at relatively short distances from their source. This leads to a decreasing proportion of ilmenites as one moves away from the source, until eventually only garnet is recovered. The composition and colour of the garnet population also changes. Proximal sediments display the entire colour range, from orange to dark violet, and both a high and low chrome content. With increasing distance from source the colour becomes dominated by violet grains, these being the most stable during transport. A characteristic feature of proximity to source is the anomalous presence of minerals which cannot survive long transport, such as fractured garnets, ilmenites showing aggregate structures, etc.

Another significant feature is an irregular pattern of anomalous mineral distribution often separated by areas in which no minerals occur. This especially meaningful if accompanied by large grains and typomorphic diversity.

\section{Discussion of the model by the example of Middle Paleozoic Mirney field}

The model is substantiated by an examination of the area around the Mirney kimberlite field up to a distance of around 70 to $100 \mathrm{~km}$ from its center. The Late Paleozoic and Mesozoic reservoirs rocks with kimberlitic minerals occur. Kimberlitic mineral host sediments close to the kimberlite fields are noted for their significant lithological and facies diversity, the patchy distribution of kimberitic minerals within them and the association between kimberlitic minerals and basal horizons in contact with the kimberlite country rocks. The kimberlitic minerals, furthermore, display high concentrations and morphological diversity close to their sources.

\subsection{Upper Paleozoic sequence}

During Late Paleozoic kimberlitic materials were transported mainly north-east. Five thin stratigraphic horizons (cyclothems) contain kimberlitic minerals in the Upper Paleozoic sequence. Two horizons were formed in the Middle Carboniferous; two more in the Late Carboniferous - Early Permian; and the last in Late Permian. Continental (alluvial talus formations) and basin (beaches, mobile shoals, etc.) environments are represented ( Afanasiev and Zinchuk, 1987; Saltykov and Erinchek, 1992). High concentrations of kimberlitic minerals are reported in the oldest (continental) and second youngest (basin) basal sediments.

The highest concentrations of kimberlitic minerals are recorded close to the field. They are confined to conglomerates, pebblestones, gritsones, sandy formations with occasional pebbles and gravel. Here kimberlitic mineral counts reached thousands (up to 12 000) of grains per 10 litre sample. Average values in this region are, however, closer to 50-200 grains per sample, with individual grains measuring up to $4 \mathrm{~mm}$ (and sometimes $8 \mathrm{~mm}$ ) although small grains predominate. Slightly abraded grains are common together with those components which are not able to withstand long transport. The lateral and vertical distribution of kimberlitic minerals is irregular.

\subsection{Mesozoic sequence}

During the Mesozoic stage of its evolution, the Mirney field, which lies within the limits of a large palaeo-rise, contributed kimberlitic minerals to the Early Mesozoic sediments accumulating within 
the field and outside of it. During this time materials were transported mainly south and southeastwards. Aureoles of kimberlitic minerals were formed adjacent to the kimberlite field in five basal horizons emplaced between the Late Triassic and the Early Jurassic. Within the first three formations, kimberlitic mineral concentrations are greatest in continental sediments (alluvial, proluvial and talus facies) within $30-40 \mathrm{kms}$ of the kimberlite field (Saltykov and Erinchek, 1992). Basin sediments of the upper two formations are noted for their low concentrations of kimberlitic minerals. In areas immediately adjacent to the kimberlite pipes, kimberlitic mineral compositions are similar to those in the source rocks and the aureoles can be directly correlated with their source. Individual features of kimberlitic minerals far removed from their source rocks become difficult to recognize and the assemblage of kimberlitic minerals becomes more homogeneous. The degree of abrasion of the kimberlitic minerals also changes markedly. Close to the pipes, the heavy concentrates are dominated by well preserved minerals, with fractured pyropes and ilmenites with aggregate structures making up to $25 \%$ of the total. The percentage of kimberlitic minerals showing little wear decreases rapidly and this can be seen at distances of only 5-10 kms. The proportion of unstable minerals is very low and often absent. Since the Mesozoic, kimberlitic mineral aureoles formed mainly under continental conditions with highest concentrations only recorded adjacent to the pipes, with a rapid fall off with increasing distance.

\section{Conclusion}

The above formulates, for the first time, the relationships between kimberlite fields and the resulting distribution of kimberlitic minerals in the associated postkimberlite terrigenous reservoirs. This model provides: (1) . thin fine-rhythmic postkimberlite series with a lot of small-amplitude cyclothems; (2) several stratigrafic levels showing elevated concentration of kimberlitic minerals; (3) lithological heterogeneity and polyfaciesty of reservoir rocks with predominant occurrence of kimberlitic minerals in proximal facies; (4) variation of the kimberlitic minerals concentration with areas of abnomaly high concentrations of minerals; (5) heterogeneous distribution and the typomorhic diversity of kimberlitic minerals. This set of feature allow to determine kimberlite fields even if they are buried.

\section{Acknowledgments}

We would like to thank Mr. K.R. Hazell for particularly helpful comments during the course of this work and his English revision of it.

\section{References}

Afanasiev, V.P. and Zinchuk, N.N., 1987, The mineralogy of ancient diamond placers in the eastern flank of Tunguss syneclise: Geologiya i Geofizika, 1, p. 90-96.

Brakhfogel, F.F., 1984, The geological aspects of kimberlite magmatism in the north-east of the Siberian platform, Yakutsk, 128 p.

Fainshtein, G.K.,1981, The main features of the Upper Paleozoic diamond-bearing sentiments structure in the eastern flank of Tunguss syneclise: Geologiya i Geofizika, 1981, 5, p.46-54

Kharkiv, A.D., 1978, The mineralogical basis of diamond deposits exploration, Moscow, Nedra, $136 \mathrm{p}$.

Saltykov, O.G., Erinchek, Yu.M., Ustinov, V.N., and Milshtein, E.D., 1991, The Late Paleozoic terrigenous collectors of diamond in the eastern flank of the Tunguss syneclise, St-Petersburg, $223 \mathrm{p}$. Saltykov, O.G., and Erinchek, Yu.M., 1992, The model of kimberlite field manifestation in terrigenios collectors of diamond satellite minerals: Doklady Rossiyskoi Academii Nauk, vol. 326, 1, p. 154-158.

Taranenko, V.I., Prokopchuk, B.I., Yanigin, Yu.T., and Shapovalova, V.P., 1983 Geomorphological conditions of diamond placers forming at the Late Paleozoic in the south-eastern flank of Tunguss syneclise: Geomorfologiya, 2, p. 48-53. 